Roger Williams University

DOCS@RWU

\title{
The Time Is Now: The Emerging Need for Master's-Level Training in Forensic Psychology
}

\author{
Matt Zaitchik \\ RogerWilliams University, mzaitchik@rwu.edu \\ Garrett Berman \\ Roger Williams University, gberman@rwu.edu \\ Don Whitworth \\ RogerWilliams University, dwhitworth@rwu.edu \\ Judith Platania \\ Roger Williams University, jplatania@rwu.edu
}

Follow this and additional works at: https://docs.rwu.edu/fcas_fp

Part of the Psychology Commons

\section{Recommended Citation}

Zaitchik, M. C., G. L. Berman, D. Whitworth, and J. Platania. 2007. "The Time is Now: The Emerging Need for master's-Level Training in Forensic Psychology."Journal of Forensic Psychology Practice 7 (2): 65-71.

This Article is brought to you for free and open access by the Arts and Sciences at DOCS@RWU. It has been accepted for inclusion in Arts \& Sciences Faculty Publications by an authorized administrator of DOCS@RWU. For more information, please contact mwu@rwu.edu. 
This article was downloaded by: [Roger Williams University]

On: 14 November 2013, At: 08:05

Publisher: Routledge

Informa Ltd Registered in England and Wales Registered Number: 1072954 Registered office: Mortimer House, 37-41 Mortimer Street, London W1T 3J H, UK

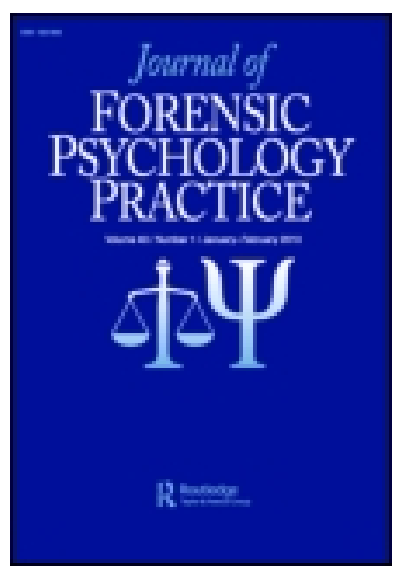

\title{
J ournal of Forensic Psychology Practice
}

Publication details, including instructions for authors and subscription information: http:// www.tandfonline.com/loi/ wfpp20

\section{The Time Is Now: The Emerging Need for Master's-Level Training in Forensic Psychology}

\author{
Matt C. Zaitchik PhD ${ }^{\mathrm{a} b}$, Garrett L. Berman PhD ${ }^{\mathrm{a}}$, Don Whitworth $\mathrm{PhD}^{\mathrm{a}}$ \& J udith Platania \\ $\mathrm{PhD}^{\mathrm{a}}$ \\ ${ }^{\text {a }}$ Roger Williams University \\ ${ }^{\mathrm{b}}$ Massachusetts Treatment Center for Sexually Dangerous Persons \\ Published online: 11 Oct 2008.
}

To cite this article: Matt C. Zaitchik PhD , Garrett L. Berman PhD, Don Whitworth PhD \& J udith Platania PhD (2007) The Time Is Now: The Emerging Need for Master's-Level Training in Forensic Psychology, J ournal of Forensic Psychology Practice, 7:2, 65-71, DOI: 10.1300/J158v07n02_05

To link to this article: http:// dx.doi.org/ 10.1300/J 158v07n02_05

\section{PLEASE SCROLL DOWN FOR ARTICLE}

Taylor \& Francis makes every effort to ensure the accuracy of all the information (the "Content") contained in the publications on our platform. However, Taylor \& Francis, our agents, and our licensors make no representations or warranties whatsoever as to the accuracy, completeness, or suitability for any purpose of the Content. Any opinions and views expressed in this publication are the opinions and views of the authors, and are not the views of or endorsed by Taylor \& Francis. The accuracy of the Content should not be relied upon and should be independently verified with primary sources of information. Taylor and Francis shall not be liable for any losses, actions, claims, proceedings, demands, costs, expenses, damages, and other liabilities whatsoever or howsoever caused arising directly or indirectly in connection with, in relation to or arising out of the use of the Content.

This article may be used for research, teaching, and private study purposes. Any substantial or systematic reproduction, redistribution, reselling, loan, sub-licensing, systematic supply, or distribution in any form to anyone is expressly forbidden. Terms \& Conditions of access and use can be found at http:// www.tandfonline.com/page/terms-and-conditions 


\title{
The Time Is Now: The Emerging Need for Master's-Level Training in Forensic Psychology
}

\author{
Matt C. Zaitchik, $\mathrm{PhD}$ \\ Garrett L. Berman, PhD \\ Don Whitworth, $\mathrm{PhD}$ \\ Judith Platania, PhD
}

\begin{abstract}
Since the inception of the first doctoral program in psychology and law in 1974, master's-level training in forensic psychology has been virtually ignored by the field of psychology and law training.
\end{abstract}

Matt C. Zaitchik received his $\mathrm{PhD}$ in Clinical Psychology from the University of Connecticut, Storrs. He is currently Associate Professor of Psychology at Roger Williams University. He is a Diplomate, American Board of Forensic Psychology, Designated Forensic Professional and Supervisor for the Commonwealth of Massachusetts, and Member of the Community Access Board at the Massachusetts Treatment Center for Sexually Dangerous Persons.

Garrett L. Berman received his PhD in Applied Psychology from Florida International University. He is currently Associate Professor of Psychology at Roger Williams University. He has authored or coauthored a number of articles related to psychology and law, such as expert testimony, legal safeguards, eyewitness memory, and juror decision-making.

Don Whitworth received his $\mathrm{PhD}$ in Clinical Psychology from the University of Rhode Island. He is Professor of Psychology and Chair of the Psychology program at Roger Williams University. He is the primary author of the Master's in Forensic Psychology program opening at Roger Williams University in Fall 2006.

Judith Platania received her $\mathrm{PhD}$ in Applied Psychology from Florida International University. She is currently an Assistant Professor of Psychology at Roger Williams University. She has worked for several years as a trial consultant. Her current research addresses jury selection and jury decision-making in capital cases.

Address correspondence to: Matt C. Zaitchik, PhD, Department of Psychology, Roger Williams University, One Old Ferry Road, Bristol, RI 02809 (E-mail: mzaitchik@rwu.edu).

Journal of Forensic Psychology Practice, Vol. 7(2) 2007

Available online at http://jfpp.haworthpress.com

(C) 2007 by The Haworth Press, Inc. All rights reserved. doi:10.1300/J158v07n02_05 
Given the changes in the workplace over the past few decades, master'slevel clinicians are providing more psychological services, often under the supervision of doctoral-level providers. Master's training programs are emerging in forensic psychology to fill the need for forensicallytrained clinicians at the master's level. This article proposes a Bifurcated Educational Model (BEM) in advocating for forensic psychology training at the master's level. Citing the Villanova Conference on Training in Law and Psychology, the authors argue for a similar approach to evaluating and improving the effectiveness in master's-level programs. doi:10.1300/J158v07n02_05 [Article copies available for a fee from The Haworth Document Delivery Service: 1-800-HAWORTH. E-mail address: < docdelivery@ haworthpress.com> Website: <http://www.HaworthPress.com> (0) 2007 by The Haworth Press, Inc. All rights reserved.]

KEYWORDS. Forensic training, forensic psychology, forensic master's, graduate training

The University of Nebraska at Lincoln established the first $\mathrm{PhD}$ program in psychology and law in 1974. Since the inception of the Nebraska program, researchers have proposed a number of training models to prepare students for careers in forensic psychology. In 1995, a national conference was held at Villanova University on issues related to training and education in psychology and law (Bersoff et al., 1997). One of the major goals of the conference was to put forward an agenda for future years at the undergraduate, graduate, and continuing professional education levels. The American-Psychology Law Society (APLS), Division 41 of the American Psychological Association (APA), is actively involved in the training and career development of psychologists within the field of psychology and law. As the field of psychology and law continues to grow, a variety of training programs will continue to develop to meet the needs of students interested in interdisciplinary study and practice.

\section{THE HISTORY OF FORENSIC PSYCHOLOGY TRAINING}

In a recent symposium on master's-level training in forensic psychology, Grisso (2005) acknowledged that considerable diversity exists in both models and training in law and psychology programs. This diversity can be seen across doctoral programs in forensic psychology, joint $\mathrm{JD} / \mathrm{PhD}$ programs, clinical psychology programs that incorporate a 
forensic psychology concentration, and postdoctoral forensic psychology programs.

Until recently, published conference proceedings addressing graduate education in psychology and law focused exclusively on the doctorate as the entry-level degree for professional careers (Bersoff et al., 1997). In fact, an examination of the reviews exploring higher education in forensic psychology (Otto, Heilbrun, \& Grisso, 1990; Roesch, Grisso, \& Poythress, 1986; Tomkins \& Ogloff, 1990) revealed only two sentences devoted to an assessment of training in the areas of forensic or legal psychology at a master's level (Grisso, Sales, \& Bayless, 1982). Additionally, The Villanova Conference, which involved several days of comprehensive discussions of the full range of training programs noted above, included no mention of existing master's degree forensic psychology training programs or the potential for developing such programs in the future (Bersoff et al., 1997). The most recent review of training in the field (Packer \& Borum, 2003) did not mention master's-level training. Although it is our contention that roles such as "expert" or "expert witness" are principally the purviews of doctoral-level practitioners and researchers, there are other roles for practitioners in forensic and legal settings that do not require doctoral-level training. Many of these roles are emerging in the changing environment due to the economic realities of the current workplace (Steir, 1998). It can be argued, therefore, that faculty responsible for the development and implementation of forensic psychology master's degree programs need to develop master's-level specific training objectives, rather than relying on the historical mainstream of training models in psychology and law (Grisso, 2005).

\section{DEVELOPING GOALS FOR MASTER'S-LEVEL TRAINING PROGRAMS}

Because mainstream law and psychology programs have had little interest in master's degree training, program administrators (as a collective body) must develop clear objectives and models. Two general models of training have been suggested for master's-level students: Programs that train practitioners and programs that train researchers. Current master's degree programs focus on one or the other of these goals. Several researchers have argued in favor of master's-level training models that encompass elements of practitioner and research training (Grisso, 2005; Studebaker, 2005; Whitworth, 2005). In this Bifurcated Educational Model (BEM), graduate students, based upon individual 
preference, select a practitioner or research track. The practitioner model leads to a terminal master's degree and a career working with forensic populations in a variety of treatment settings. There are a number of responsibilities conducive to these settings that do not require doctoral-level training. These include mental health screening, referral, diversion, and case description and formulation. Additionally, group therapy sessions are often facilitated by master's-level clinicians. Administrators of master's programs in psychology may also consider focusing on training master's degree forensic psychology specialists for a collaborative relationship with doctoral forensic psychology professionals who would have a supervisory role. In such a case, the master's-level clinician would be responsible for helping to manage the professional tasks and cases that have always been the focus of doctoral-level forensic psychologists.

Students completing a research track in a forensic psychology master's BEM will have similar course requirements with additional methodological training and a required thesis. These students could be employed as researchers or competitively apply for entrance into $\mathrm{PhD}$ or PsyD programs in a variety of specialty areas including counseling, clinical, forensic, and legal psychology or choose to pursue a dual degree program $(\mathrm{JD} / \mathrm{PhD})$ in psychology and law. One researcher explained this two track model as being analogous to those that exist at the doctoral level between PsyD and PhD programs (Studebaker, 2005).

Heilbrun (2005) argued that master's-level training "when done properly" can provide students who are interested in pursuing doctoral-level training with "several distinct advantages." These advantages include a more realistic view of the field, an enhanced capacity to make informed distinctions between various forensic subspecialties, a greater familiarity with the relevant scientific and practice literatures, the opportunity for more research experience, the availability of more clinical-forensic experience, and training under faculty who may be known to other faculty at doctoral programs. Heilbrun also noted that master's-level clinicians/researchers can work either independently or under the supervision of a doctoral-level psychologist, depending upon setting and task.

\section{THE EMERGENCE OF FORENSIC PSYCHOLOGY MASTER'S PROGRAMS}

Although master's-level training has largely been ignored by the broader field of law and psychology training, there have been an in- 
creasing number of such programs nationwide. This growth may reflect a growing job market for forensically trained master's-level clinicians in correctional facilities, forensic treatment centers, and juvenile justice settings who seek master's-level clinicians to provide services. Just as the field of clinical psychology has changed dramatically since the inception of the Boulder model (as the roles for clinical practitioners expanded exponentially), the delivery of psychological services has changed over the past few decades. Increasingly, doctoral-level psychologists are in supervisory roles and master's-level clinicians (including social workers) are providing direct services (Colliver, Havens, \& Wesley, 1985; MacKain, Tedeschi, Durham, \& Goldman, 2002; Steir, 1998; Trent, 1993). This trend has been apparent both in forensic and non-forensic settings. It appears that the question is not "Is there a need for master's-level clinicians?" but "How can we best prepare master'slevel clinicians to work in the current job market?"

Although forensic psychology master's programs have developed over recent years, there has not been an organized attempt to develop and evaluate training models. To our knowledge, the first discussion regarding master's-level training programs took place in 2005 at the APLS Conference in La Jolla, California (Zaitchik \& Berman, 2005). In this symposium, both theoretical and practical concerns were discussed regarding the emergence of master's specialized training in forensic psychology. Studebaker (2005) raised questions regarding the "level and content of training and education at the master's level. For example, what is the minimal amount of acceptable training?" Whitworth (2005) addressed the unique challenges associated with the planning, marketing, and implementation of a new program at Roger Williams University. He noted that the first step in the process involved a discussion about what type of program would most benefit students. That is, did the university seek to train practitioners, researchers, or both? In reviewing extant programs around the country as well as potential internships and job opportunities, it was decided that the program would include two tracks: one that focused primarily on training practitioners and one that focused on a research component. It was believed that students who chose the latter track would likely be preparing for later doctoral-level training. In developing the curricula for these tracks, care was taken to tailor the sequence of courses to the stated goals.

Another area that needs to be considered in the development and training of forensic psychology master's-level practitioners is the practicum placement. Whitworth (2005) noted that the relationship between the university and practicum/internship sites is a crucial component of the pro- 
gram. As noted by Patry (2005), the set-up and supervision of internships "often requires substantial time and effort on the part of the faculty member." Proposed practicum sites may include jails, youth detention centers, court clinics, a treatment center for sex offenders, and psychiatric facilities with forensic patients, among others (Whitworth, 2005).

\section{CONCLUSIONS}

Since the opening of the Nebraska program and the ensuing Villanova Conference on training in psychology and law programs, there has been a recent increase in the interest in the development of training programs at the master's level. New programs have grown out of the need to accommodate the changing environment for forensic service delivery. It is our belief that the support and acceptance of these new programs and the philosophies they espouse need to be examined in the context of the need they seek to address. The broader field of psychology and law, though historically focused on the doctoral-level practitioner or researcher, needs to assist in the creation of guidelines and models for training the new master's candidates. Just as the Villanova Conference in 1995 addressed the need for a "concerted effort to evaluate current training models" at the doctoral level, we call for a similar approach to evaluating and improving the effectiveness of master's-level programs.

\section{REFERENCES}

Bersoff, D. N., Goodman-Delahunty, J., Grisso, T., Hans, V. P., Poythress, N. G., \& Roesch, R. G. (1997). Training in law and psychology: Models from the Villanova conference. American Psychologist, 52, 1301-1310.

Colliver, J. A., Havens, R. A., \& Wesley, R. M. (1985). Doctoral and master's-level clinical psychologists and MSWs in public mental health settings: A nationwide follow-up. Professional Psychology: Research and Practice, 16, 634-640.

Grisso, T. (2005, March). Master's degree forensic psychology programs and the history of law-psychology training. In M. C. Zaitchik \& G. L. Berman (Chairs), Emergence of master's level forensic training programs: Roles and goals. Symposium conducted at the American Psychology-Law Society Conference, La Jolla, CA.

Grisso, T., Sales, B. D., \& Bayless, S. (1982). Law-related courses and programs in graduate psychology departments. American Psychologist, 37, 267-278.

Heilbrun, K. (2005, March). Specialty training in forensic psychology at the master's level: Implications for further training and for employment. In M. C. Zaitchik \& G. L. Berman (Chairs), Emergence of master's level forensic training programs: 
Roles and goals. Symposium conducted at the American Psychology-Law Society Conference, La Jolla, CA.

MacKain, S. J., Tedeschi, R. G., Durham, T. W., \& Goldman, V. J. (2002). So what are master's-level psychology practitioners doing? Surveys of employers and recent graduates in North Carolina. Professional Psychology: Research and Practice, 33, 408-412.

Otto, R. K., Heilbrun, K., \& Grisso, T. (1990). Training and credentialing in forensic psychology. Behavioral Sciences and the Law, 8, 217-232.

Packer, I. K. \& Borum, R. (2003). Forensic training and practice. In A. M. Goldstein (Ed.), Handbook of Psychology: Forensic Psychology. Vol. 11 (pp. 21-32). Hoboken, NJ: John Wiley \& Sons, Inc.

Patry, M. (2005, March). Internships and job placements for master's level students in forensic psychology. In M. C. Zaitchik \& G. L. Berman (Chairs), Emergence of master's level forensic training programs: Roles and goals. Symposium conducted at the American Psychology-Law Society Conference, La Jolla, CA.

Roesch, R., Grisso, T., \& Poythress, N. G. (1986). Training programs, courses, and workshops in psychology and law. In M. F. Kaplan (Ed.), The Impact of Social Psychology on Procedural Justice (pp. 83-108). Springfield, IL: Charles C. Thomas.

Steir, M. E. (1998). The great debate: Masters level licensure in psychology. Journal of Psychological Practice, 4(1), 20-27.

Studebaker, C. (2005, March). Master's programs in forensic psychology: Training researchers or practitioners? In M. C. Zaitchik \& G. L. Berman (Chairs), Emergence of master's level forensic training programs: Roles and goals. Symposium conducted at the American Psychology-Law Society Conference, La Jolla, CA.

Trent, J. T. (1993). Issues and concerns in master's-level training and employment. Journal of Clinical Psychology, 49, 586-592.

Tomkins, A. J. \& Ogloff, J. R. P. (1990). Training and career options in psychology and law. Behavioral Sciences and the Law, 8, 205-216.

Whitworth, D. (2005, March). Planning, marketing, and implementing forensic masters programs: Roger Williams University: A brief case example. In M. C. Zaitchik \& G. L. Berman (Chairs), Emergence of master's level forensic training programs: Roles and goals. Symposium conducted at the American Psychology-Law Society Conference, La Jolla, CA.

Zaitchik, M. C. \& Berman, G. L. (2005, March). Emergence of master's level forensic training programs: Roles and goals. Symposium presented at the American Psychology-Law Society Conference, La Jolla, CA.

RECEIVED: $12 / 21 / 05$

REVISED: $12 / 21 / 05$

ACCEPTED: 12/21/05

doi:10.1300/J158v07n02_05 